\title{
Approach to assessment of the degree of adaptivity of business associations to external challenges
}

\author{
Oksana Pirogova ${ }^{1 *}$, Irina Zhilinkova ${ }^{1}$, and Marina Makarevich ${ }^{1}$ \\ ${ }^{1}$ Peter the Great St. Petersburg Polytechnic University, 195251, 29 Polytechnicheskaya str., St. \\ Petersburg, Russia
}

\begin{abstract}
Creation of an enabling environment for small and mediumsized businesses in the service sector, most affected by the COVID-19 pandemic, is one of the most pressing challenges of the moment as never before. The purpose of the study is to analyze the current trends in the activities of business associations in a pandemic. Research objectives: to study the problems of SMEs, to consider the degree of adaptation of business associations to the crisis conditions caused by the pandemic. The study used the following methods: description, comparison, analogy and generalization, aggregation, analysis and synthesis. The results of the work are: analysis of the destabilizing factors that determine the current trends in the development of business associations; identification of promising types of commercial business services provided by business associations at the present time; author's approach to determining the economic effect of digitalization; an assessment of the economic effect of digitalization on the example of calculating the cost of one of the most demanded commercial services provided by business associations - a consulting seminar held online and offline.
\end{abstract}

\section{Introduction}

The list of industries predominantly affected by the COVID-19 pandemic is, for the most part, service industries: transport, culture, leisure and entertainment, fitness and sports, travel agencies and other organizations providing services in the field of tourism, hotel business and catering. Enterprises in these industries are predominantly small and mediumsized businesses. (or entrepreneurship, hereinafter referred to as SME / E). The service industry has been hit hard by the coronavirus pandemic. Most entrepreneurs are pessimistic about the prospects for the normalization of the situation in their industry.

Business associations, which are non-profit associations of entrepreneurs, are capable of reducing the degree of tension in the service sector markets and giving the necessary impetus to the recovery of financial and economic indicators of SMEs.

The share of small and medium-sized businesses in the Russian Federation during the first two decades of the 21 st century is noticeably lower than in industrialized countries,

* Corresponding author: kafedra17@rambler.ru 
despite the target indicators for the development of SMEs, which the Russian government is striving for in the adopted roadmaps of national projects. The share of small and medium-sized businesses in GDP in 2019 was 8.56\%. As of August 10, 2020, only 15.5 million people were employed in this sector [1].

Most of the SMEs are concentrated in the service sector. They provide employment to a significant percentage of the population of the Russian Federation. According to the estimates of leading industry business associations, such as the Association of Fitness Operators, the Federation of Restaurateurs and Hoteliers, the Association of Tour Operators of Russia (ATOR) and more than 60 representatives of other business associations, 5.5 million Russians are employed. The share of the average number of employees in small and medium-sized enterprises in the average number of employees by type of economic activity is shown in Figure 1.

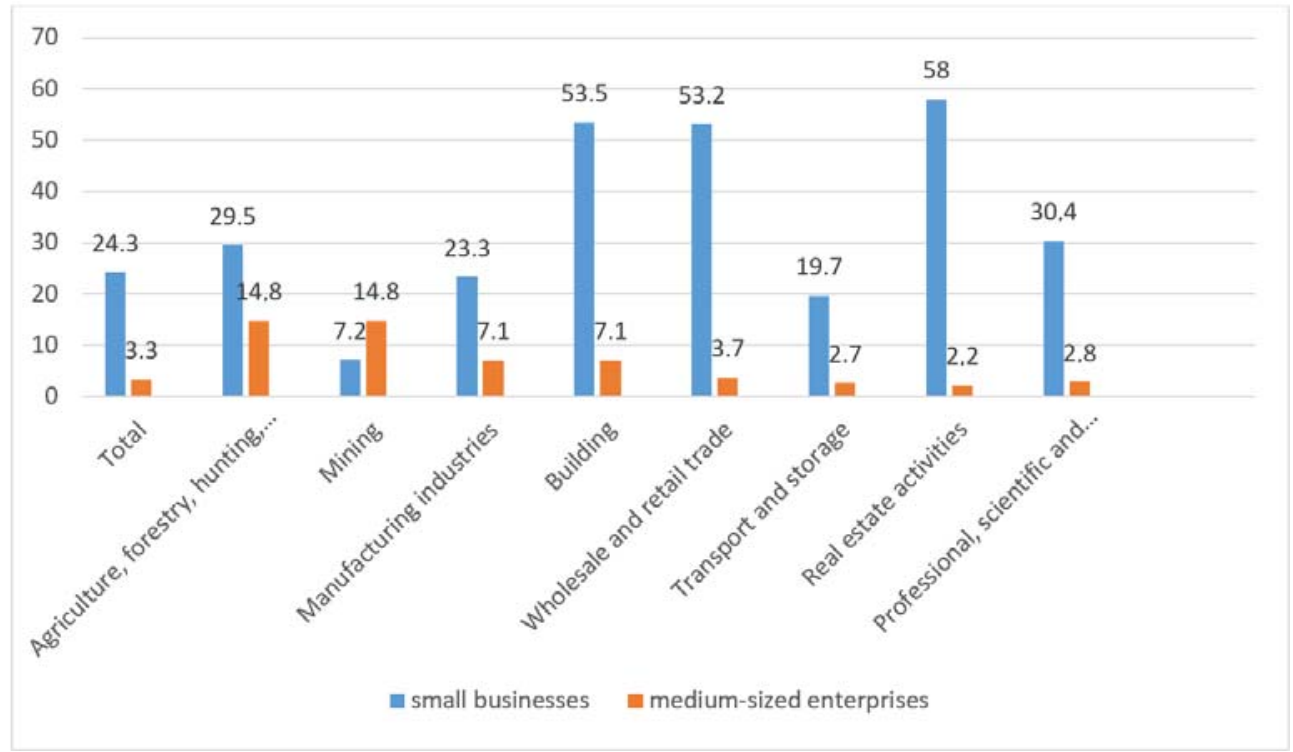

Fig. 1. The share of the average number of employees (without external part-time workers) of small and medium-sized enterprises in the average number of employees (without external part-time workers) of all enterprises and organizations by type of economic activity.

The total amount of tax payments transferred to the budget by industry enterprises is almost 1 trillion rubles. per year, including 202 billion - personal income tax and social benefits [2].

At present, the general macroeconomic situation in the Russian Federation is characterized by the following indicators:

- GDP in the Russian Federation at the end of the pandemic 2020 fell by 3.1\%;

- domestic final demand decreased by $5 \%$;

- the unemployment rate increased from $4.5 \%$ in September 2019 to $6.3 \%$ in October 2020.

Due to the difficulty of transferring the business processes of the service sector to remote work, in connection with the introduction of restrictive measures, it was this sector that suffered the most from the socio-economic consequences of the coronavirus infection. Value added decreased by $24.1 \%$ in the hotel and restaurant business, by $11.4 \%$ in cultural and sports establishments, by $10.3 \%$ in transport companies, and in other service 
enterprises by $6.8 \%$ [3]. The fall of the Russian economy due to the pandemic was the maximum in 11 years $\mathrm{RBC}$.

In total:

- up to 500 thousand people were left without work in the retail and hospitality industry (in each of these segments)

- the decline in real wages was $11.0 \%$ in the hospitality industry, $5.8 \%$ in construction, $4.1 \%$ in retail [4].

The general problems for all selected sectors during the pandemic against the background of general uncertainty were a decrease in revenue due to a drop in consumer demand, the risk of infection of employees, imperfection of the anti-crisis management system, and interruptions in supply chains. At the end of last year, business financial performance deteriorated by one third in 48 out of 85 regions of Russia. The share of companies that are in a critical situation, that is, they are not able to service the main debt or pay taxes, insurance premiums, salaries, etc., is $20.9 \%$. Most entrepreneurs are pessimistic about the prospects for the normalization of the situation in their industry. Almost half (43\%) believe that the situation will return to normal not earlier than in a year. Thus, the service sector has been significantly affected by the coronavirus pandemic..

\section{Materials and Methods}

External and internal socio-economic shocks at all times led to the activation of the process of self-organization of the entrepreneurial community. The global financial crisis of 2008, the imposition of economic sanctions in 2014 and, of course, the COVID-19 pandemic can be called such triggering events in the 21 st century for the Russian economic space [5].

Currently, a total of 17 thousand business associations are registered in the Russian Federation in the form of non-profit partnerships, federations, chambers of commerce, unions, and business associations. Of $100 \%$ of all business associations, $23.5 \%$, as expected, are registered in Moscow. Not all existing public organizations can be fully identified as entrepreneurial unions, which aim to promote the development of their members' businesses and improve the business climate in the industry. The lack of detailed information by the Ministry of Justice regarding the nature and direction of activities of registered public organizations, in our opinion, is a significant brake both in relation to the qualitative processes of the industry consolidation of the entrepreneurial community, and in relation to the regulation and regulation of the activities of business associations themselves [6].

Not all declared business associations are efficient. The main public source of information on the activities of such structures remains the websites of organizations. However, some of the business associations still lack sites, or the existing sites are so inoperative that they are completely uninformative and useless both for their potential or current members, if any, and for researchers of this topic. Single business associations are ready to provide charters, founding documents, reports on their activities, minutes of meetings and other official documentation on the pages of their website [7]. The scale of activity of a particular business association and the degree of involvement of industry enterprises in the work of professional, industry and other entrepreneurial organizations must be judged based on digests, press releases and news feeds. Therefore, the adoption of normative legal acts (RLA) aimed at expanding transparency and streamlining the work of such entrepreneurial integration entities will contribute to the further reorganization of the institutions of self-organization of entrepreneurs and the formation of a favourable entrepreneurial competitive environment. A significant event in this regard is the publication in 2020 of a verified register of TOP 300 industry associations and business associations, prepared by analysts of the Public Relations Development Company (PRDC) 
in conjunction with the Russian Association for Public Relations (RAPR) [8]. Based on this register, a rating of industries was compiled according to the total communication activity of industry business associations in the past year. Significantly, it was chaired by business associations operating in the sectors most affected by the pandemic: travel, trade, insurance and financial services. Nevertheless, it should be recognized that the effectiveness of a business association from the point of view of its members is not always determined only by publication activity in the Internet space [9]. Thus, the lack of objective information about the functioning of business associations remains a significant obstacle to expanding their client base. A special re-engineering of the activities of most industry business associations during a pandemic is aimed at developing strategies to rebuild their members' businesses (Figure 2)

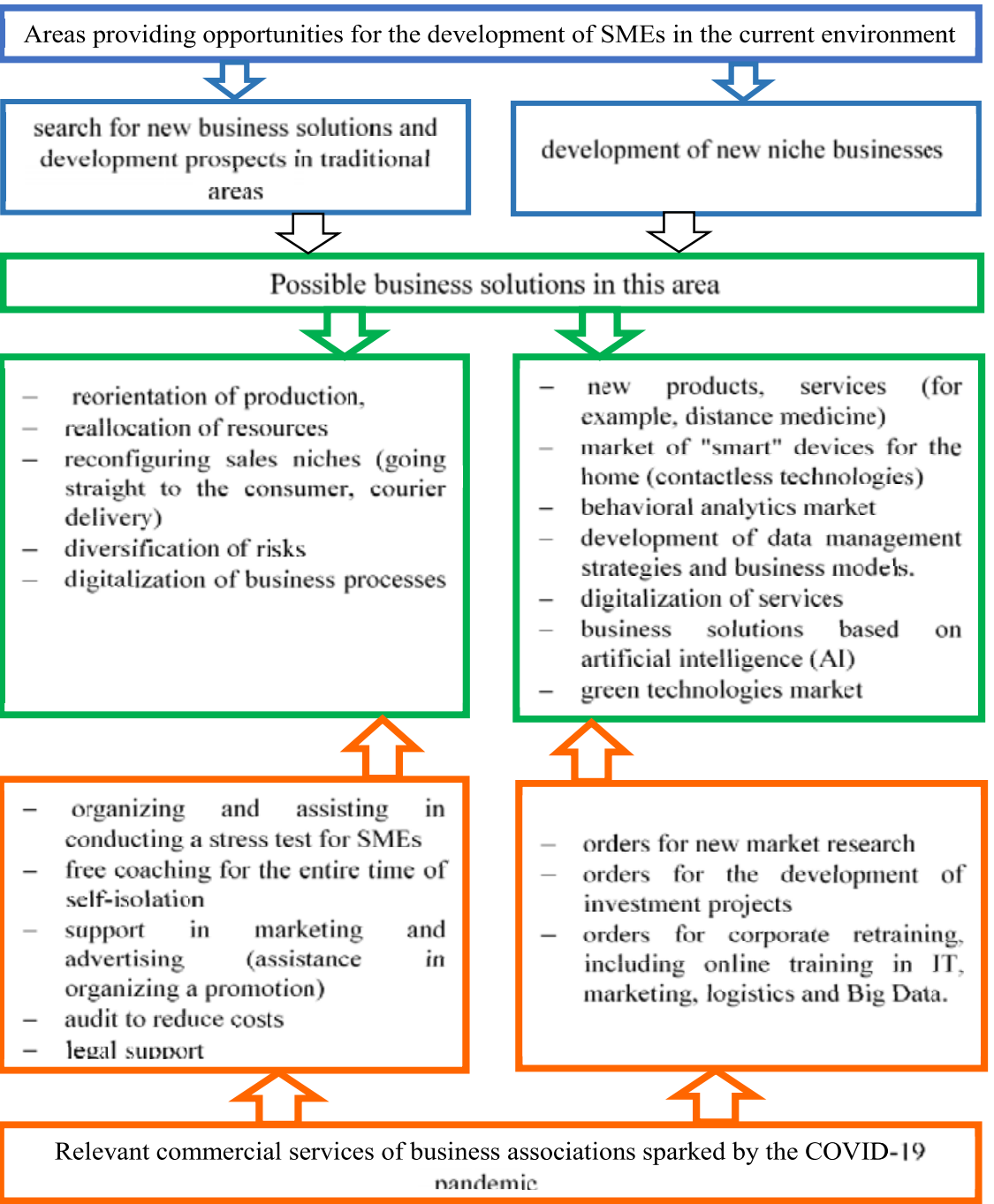

Fig. 2. Commercial services of business associations that contribute to the development of the most relevant areas for the recovery of SMEs in the context of the COVID-19 pandemic. 


\section{Results and discussion}

Most of the sectoral business associations, being an important institution for the selforganization of the business community, also could not help but experience the negative impact of the pandemic on their activities. In particular, a significant portion of regional industry business associations faced [10-12]:

- reducing the opportunity for personal communication;

- $\quad$ an increase in the number of problematic and suspended companies;

- reduction of the base of membership fees.

Digital technologies are currently one of the possible ways to optimize the activities of business associations. The digital transformation of the business services provided to its members significantly reduces the costs of business associations [13-15]. At the same time, undergoing digital transformation, business associations act as a catalyst for digitalization in industry markets.

The calculation of the annual / quarterly economic effect from the digitalization of commercial services provided by business associations to their members can be calculated using the formula (1):

$$
E=(C 1-C 2) * A \mathrm{y}
$$

where, $C_{1}$ and $C_{2}$ - are the costs per unit of volume of commercial services rendered, performed respectively without the use of digital technologies and with the use of digital technologies, rubles.

$A_{\mathrm{y}}$ - the annual / quarterly / monthly volume of commercial services rendered by business associations, performed in the reporting year using digital technologies, in appropriate units of measurement, for example, the number of activities carried out, projects implemented, examinations, etc.

The list of typical digitalizable commercial services provided by industry business associations to their members includes organizing and conducting:

- event forums / conferences / congresses / meetings / rallies / round tables / trips of delegations / excursions.

- educational lectures / seminars / master classes / trainings / coach sessions / consultations.

- thematic exhibitions / presentations / promotions /

- expertise of the business process, product, project / conclusions on the assessment of regulatory impact /

- marketing research / stress test / audit / legal advice / technical assistance.

We will carry out a comparative analysis of the cost price of a consulting seminar / training / master class in offline and online format (in the form of a webinar), i.e. without the use of digital technologies and with the use of digital technologies, a business association that meets the following quality characteristics:

- business association, is an entrepreneurial union of enterprises in the service sector

- most of the current members of the business association are SMEs

- business association in the service sector, operating in the industry segment most affected by the COVID-19 pandemic

- a business association provides commercial services (which is confirmed by crosschecking information from open sources, (reports of business associations, press releases, etc.)

- the business association has existed on the market for more than $5 / 10$ years, therefore, it is possible to estimate the cost of the commercial service provided before and after the digitalization of business processes in the organization 
With all the variety of existing industry associations, there are not so many business associations that would fully meet the selected criteria. The list of business associations that meets the necessary requirements can include the National Association of Event Organizers (NAEO, founded in 2008), the Russian Association of Marketing Services (RAMS, founded in 2001), and the Russian Hotel Association (RHA, founded in 1997).

The type of service chosen as the object of research is the organization and conduct of consulting seminars by the business association in the form of one-time two-hour sessions that are not subject to licensing. These events are not accompanied by the final certification of the participants and do not require the issuance of educational documents to them [16]. Obviously, this service is universal and is present in the list of commercial services of all selected business associations.

We will calculate the cost of the consultation seminar. The calculation of the cost price of the consulting seminar was carried out in an analogous way [17]. The average cost was determined from the rates for estimates for the same events, taking into account the rate card of rates in the marketing services market of the RAMU and taking into account the threshold rates for the cost of 1 working hour of the corresponding specialist in the current year in Moscow. The number of events to be held was calculated in accordance with the $2019 / 2020$ activity plans adopted by the business association. It is not currently possible to determine the cost price using the resource method and the index method, as well as the actual volumes of services provided, in view of:

- lack of reliable and complete information in open sources about the actual events carried out during the year;

- absence in open sources of financial and accounting reports on the activities of the business association.

The calculation of the cost of organizing and conducting offline events is shown in Table 1.

Table 1. Estimated costs for organizing and conducting a 2-hour offline event (consultation seminar), the number of participants - up to 100 people for 2018/2019.

\begin{tabular}{|c|c|c|c|c|c|}
\hline № & Expense item name & Units & $\begin{array}{l}\text { Price, in rubles } \\
\text { (from / to) }\end{array}$ & Number & $\begin{array}{c}\text { Amount, rub } \\
\text { (from / to) }\end{array}$ \\
\hline 1. & $\begin{array}{l}\text { Room rental: Conference hall } 120 \mathrm{~m}^{2} \text {, } \\
\text { Moscow }\end{array}$ & $\begin{array}{c}\text { RUB / } \\
\text { hour }\end{array}$ & $\begin{array}{c}2500 / \\
6000\end{array}$ & $2 \mathrm{~h}$. & $\begin{array}{c}5000 / \\
12000\end{array}$ \\
\hline 2. & $\begin{array}{l}\text { PR-events: Social (SMM), event } \\
\text { announcements for the media and in } \\
\text { social networks, preparation of printed } \\
\text { materials (flyers, posters), photo and } \\
\text { video filming, post-release writing }\end{array}$ & $\begin{array}{l}\text { RUB / } \\
\text { hour }\end{array}$ & $\begin{array}{c}3199 / \\
7108\end{array}$ & $8 \mathrm{~h}$. & $\begin{array}{c}25590 / \\
56865\end{array}$ \\
\hline 3. & $\begin{array}{l}\text { Purchase of stationery (pen, notebook, } \\
\text { folder, Whatman paper, etc.) / cost of } \\
\text { presentation materials, souvenirs, gifts }\end{array}$ & $\begin{array}{l}\text { RUB / } \\
\text { person }\end{array}$ & $\begin{array}{l}100 / \\
500\end{array}$ & 100 & $\begin{array}{l}10000 / \\
50000\end{array}$ \\
\hline 4. & $\begin{array}{l}\text { Catering / Mineral water and disposable } \\
\text { dishes / coffee - break / }\end{array}$ & $\begin{array}{l}\text { RUB / } \\
\text { person }\end{array}$ & $\begin{array}{l}200 / \\
500\end{array}$ & 100 & $\begin{array}{l}20000 / \\
50000\end{array}$ \\
\hline 5 & $\begin{array}{l}\text { Payment for the services of invited } \\
\text { presenters / lecturers / experts, } \\
\text { considering deductions to (transfer, } \\
\text { accommodation) insurance funds }\end{array}$ & $\begin{array}{l}\text { RUB / } \\
\text { hour }\end{array}$ & $\begin{array}{c}1500 / \\
35000\end{array}$ & $2 \mathrm{~h}$ & $\begin{array}{l}3000 / \\
70000\end{array}$ \\
\hline 6. & $\begin{array}{l}\text { Payment for services to the organizers } \\
\text { of the event, considering deductions to } \\
\text { insurance funds (work with clients) }\end{array}$ & $\begin{array}{l}\text { RUB / } \\
\text { hour }\end{array}$ & $\begin{array}{l}1894 / \\
3534\end{array}$ & $8 \mathrm{~h}$. & $\begin{array}{l}15152 / \\
28272\end{array}$ \\
\hline 7. & Total: line $1+2+3+4+5+6$ & & & & $\begin{array}{l}78742 / \\
267137 \\
\end{array}$ \\
\hline 8. & Unexpected expenses & & $\begin{array}{l}15 / 25 \% \text { of the } \\
\text { total amount }\end{array}$ & & $\begin{array}{c}11811,3 / \\
66784 \\
\end{array}$ \\
\hline 9 & TOTAL for the event: line $7+8\left(\boldsymbol{C}_{1}\right)$ & & & & $\begin{array}{l}90553 / \\
333921\end{array}$ \\
\hline
\end{tabular}


Table 2. Total cost estimate for organizing and conducting an online event (webinar) up to 100 people for 2018/2019.

\begin{tabular}{|c|c|c|c|c|c|}
\hline № & Expense item name & Units & $\begin{array}{c}\text { Price, in rubles } \\
\text { (from / to) }\end{array}$ & Number & $\begin{array}{c}\text { Amount, rub } \\
\text { (from / to) }\end{array}$ \\
\hline 1 & Equipment & & & & \\
\hline 1.1. & $\begin{array}{l}\text { - laptop (built-in camera } \\
\text { and microphone) / PC / } \\
\text { external camera and } \\
\text { microphone / tablet / } \\
\text { smartphone }\end{array}$ & Pcs & $\begin{array}{l}100000 / \\
350000\end{array}$ & $1 / 1 / 1$ & $\begin{array}{l}100000 / \\
350000\end{array}$ \\
\hline 1.2 . & $\begin{array}{l}\text { Network internet } \\
\text { connection }\end{array}$ & $\begin{array}{c}\text { RUB / } \\
\text { year }\end{array}$ & $\begin{array}{l}4800 / \\
12000\end{array}$ & - & $\begin{array}{l}4800 / \\
12000\end{array}$ \\
\hline 1.3 . & $\begin{array}{l}\text { - dedicated internet for } \\
\text { broadcasts }\end{array}$ & $\begin{array}{c}\text { RUB / } \\
\text { year }\end{array}$ & $\begin{array}{l}12000 / \\
43200\end{array}$ & - & $\begin{array}{l}12000 / \\
43200\end{array}$ \\
\hline 1.4 . & $\begin{array}{l}\text { - Zoom- video } \\
\text { conferencing software } \\
\text { OBS to Apps in (or } \\
\text { similar program) }\end{array}$ & $\begin{array}{l}\text { RUB / } \\
\text { year }\end{array}$ & $\begin{array}{c}150 / 350 \$ 13 a \\
\text { (Average nominal } \\
\text { USD / RUB } \\
\text { exchange rate } \\
-71,94 \text { rub./\$1) in } \\
2020)\end{array}$ & - & $\begin{array}{l}10791 / \\
25179\end{array}$ \\
\hline 1.5 . & $\begin{array}{l}\text { Website hosting, } \\
\text { mailing service (ESP) }\end{array}$ & $\begin{array}{c}\text { RUB / } \\
\text { year }\end{array}$ & $2400 / 6400$ & - & $\begin{array}{l}2400 / \\
6400\end{array}$ \\
\hline 1.6 . & $\begin{array}{l}\text { TOTAL equipment: line } \\
1.1 .+1.2+1.3+1.4+1.5\end{array}$ & $\begin{array}{c}\text { RUB / } \\
\text { year }\end{array}$ & & - & $\begin{array}{l}129991 / \\
436779 \\
\end{array}$ \\
\hline 1.7 . & $\begin{array}{l}\text { TOTAL equipment, in } \\
\text { terms of } 1 \text { hour of } \\
\text { operation: line. } 1.6 / 8760\end{array}$ & $\begin{array}{c}\text { RUB / } \\
\text { hour }\end{array}$ & & $\begin{array}{c}8760 \text { hours } \\
\text { a year }\end{array}$ & $\begin{array}{l}15 / \\
49\end{array}$ \\
\hline 1.8 . & $\begin{array}{l}\text { TOTAL equipment, } \\
\text { share of costs (rubles) } \\
\text { for equipment during } 2 \\
\text { hours of the seminar }\end{array}$ & $\begin{array}{l}\text { RUB / } \\
\text { hour }\end{array}$ & $\begin{array}{l}15 / \\
49\end{array}$ & $2 \mathrm{~h}$. & $\begin{array}{c}20 / \\
98\end{array}$ \\
\hline 2. & PR events & $\begin{array}{l}\text { RUB / } \\
\text { hour }\end{array}$ & $\begin{array}{l}3199 / \\
7108\end{array}$ & $8 \mathrm{~h}$. & $\begin{array}{l}25590 / \\
56865\end{array}$ \\
\hline 3. & $\begin{array}{l}\text { Payment for the services } \\
\text { of invited presenters / } \\
\text { lecturers / experts, } \\
\text { taking into account } \\
\text { deductions to (transfer, } \\
\text { accommodation) } \\
\text { insurance funds }\end{array}$ & $\begin{array}{l}\text { RUB / } \\
\text { hour }\end{array}$ & $\begin{array}{c}1500 / \\
35000\end{array}$ & $2 \mathrm{~h}$ & $\begin{array}{l}3000 / \\
70000\end{array}$ \\
\hline 4. & $\begin{array}{l}\text { Payment for services to } \\
\text { the organizers of the } \\
\text { event, taking into } \\
\text { account deductions to } \\
\text { insurance funds } \\
\text { (marketer, moderator, } \\
\text { curators of speakers, } \\
\text { technical specialists) }\end{array}$ & $\begin{array}{l}\text { RUB / } \\
\text { hour }\end{array}$ & $\begin{array}{l}1894 / \\
3534\end{array}$ & $8 \mathrm{~h}$. & $\begin{array}{l}15152 / \\
28272\end{array}$ \\
\hline 5 & Total: line $1.8+2+3+4$ & & & & $43743 / 85137$ \\
\hline 6 & Unexpected expenses & & $\begin{array}{l}15 / 25 \% \text { of the } \\
\text { total amount }\end{array}$ & & $\begin{array}{l}6561.45 / \\
21284.25\end{array}$ \\
\hline 7 & Total: line $5+6\left(C_{2}\right)$ & & & & $\begin{array}{l}50304.45 / \\
106421.25\end{array}$ \\
\hline
\end{tabular}

Thus, the economic effect of the use of digital technologies, as exemplified by the Russian Hotel Association (RHA), which, according to a report in 2020, held five webinars in May, is estimated from 201242.75 rubles to 1137498.75 rubles in accordance with the applicable cost estimate.

The resulting economic effect compensates for the investment costs in fixed assets (equipment) that the business association was supposed to carry out when transferring its 
activities to the online format, provided that at least 3 webinars for the budget option and 2 webinars for the VIP option are held.

Table 3. Calculation of the economic effect from the use of digital technologies on the example of the activities of the Regional State Administration (May 2020).

\begin{tabular}{|c|c|c|c|c|c|}
\hline & $\begin{array}{l}\text { Costs per } \\
\text { unit volume } \\
\text { of } \\
\text { commercial } \\
\text { services } \\
\text { rendered, } \\
\text { performed } \\
\text { accordingly } \\
\text { without the } \\
\text { use of digital } \\
\text { technologies, } \\
\text { rubles }\end{array}$ & $\begin{array}{l}\text { Costs per unit } \\
\text { volume of } \\
\text { commercial } \\
\text { services } \\
\text { rendered, } \\
\text { performed } \\
\text { respectively } \\
\text { using digital } \\
\text { technologies, } \\
\text { rub }\end{array}$ & & $\begin{array}{l}\text { Volume of } \\
\text { commercial } \\
\text { services } \\
\text { rendered } \\
\text { by RGA } \\
\text { (webinars) } \\
\text { in May } \\
2020, \text { pcs }\end{array}$ & $\begin{array}{l}\text { Economic effect } \\
\text { from digitalization } \\
\text { of commercial } \\
\text { services, rubles }\end{array}$ \\
\hline & $\left(C_{1}\right)$ & $\left(C_{2}\right)$ & $\left(C_{1}-C_{2}\right)$ & $A_{\mathrm{y}}$ & $E=\left(C_{1}-C_{2}\right) * A_{\mathrm{y}}$ \\
\hline $\begin{array}{l}\text { Option 1 } \\
\text { (budget) }\end{array}$ & 90553 & 50304.4 & 40248.55 & 5 & 201242.75 \\
\hline Option 2 (VIP) & 333921 & 106421.25 & 227499.75 & 5 & 1137498.75 \\
\hline
\end{tabular}

Additional sources of income after a webinar for a business association can be sales of:

- webinar videos;

- broadcasts;

- additional partner packages;

- individual partner options.

Expanding an absentee client audience through post-binary sales of copyrighted content is, among other things, an additional resource that increases the reputation capital of the business association (goodwill) and the business association's brand awareness in the business environment.

According to experts, by $2025,43 \%$ of companies plan to reduce the number of jobs due to the introduction of digital technologies, therefore, in order to adapt to new conditions, $40 \%$ of employees will have to retrain, more than $70 \%$ will have to acquire new skills or improve existing ones. Therefore, the growth in demand for corporate educational services, including those provided by business associations, is steadily growing. For example, "... Russia lacks from 500 thousand to 1 million specialists in various fields of information technology. At the same time, Russian universities offer only 80 thousand budget-funded places in IT specialties," the ministry said. Russia has a catastrophic shortage of IT specialists. Equalizing the imbalances in labor markets caused by digitalization, which the COVID-19 pandemic has pushed businesses to, is one of the urgent tasks that are on the agenda of the business community.

\section{Conclusion}

After analyzing the trends observed in the markets during the year, we can conclude that Russian business associations demonstrate the ability to quickly reconfigure their activities in a crisis caused by the coronavirus pandemic. This indicates a high degree of institutional maturity of this type of entrepreneurial integration structures, which is manifested in the creation of effective communication channels between the business community and the state, in the explosive growth in the number of legislative initiatives aimed at stabilizing traditional industry markets and the formation of new industry niches. Thus, the change in the structure of services of business associations is a reaction to external and internal challenges of the current moment. 
Nevertheless, a certain obstacle to the development of the entrepreneurial movement is the lack of objective information on the scale and results of the socio-economic activities of industry business associations. In this regard, the issue of improving the regulatory and legal framework based on which business associations operate in the Russian Federation is emerging with renewed vigor.

A comparative analysis of the cost estimate for organizing and conducting a consulting seminar allows us to conclude that it is possible to reduce the cost of this commercial service due to digitalization from 30 to $50 \%$. Significant savings on the cost of just one online event allows you to reduce the return on investment in fixed assets, due to the transition of business organizations from offline to online format, up to one year. Thus, the use of digital technologies can significantly reduce the level of costs, obtain additional sources of income and thereby increase the market stability of industry business associations in an environment of uncertainty. Mobilizing the work of all institutional sectors, which includes business associations, can improve the effectiveness of economic policies and reduce the burden of public spending aimed at restoring enterprises that are hit hardest by the pandemic.

\section{References}

1. B.S. Klaas, M. Klimchak, M. Semadeni, J.J. Holmes, Journal of Business Venturing, 25, 349-360 (2010), https://doi.org/10.1016/j.jbusvent.2008.12.002

2. A.E. Castillo, G.V. Pacheco, L. Hernández-Fernández, E.N. Manotas, J. Silva, Procedia Computer Science, 160, 567-572 (2019), https://doi.org/10.1016/j.procs.2019.11.046L.

3. M. Prys, J. Krysińska, P. Janaszkiewicz, P. Winiecki, P. Różewski, Computer Science, 126, 1197-1205 (2018), https://doi.org/10.1016/j.procs.2018.08.060

4. P. Gomes, Z. Kuehn, Review of Economic Dynamics, 26,164-179, (2017), https://doi.org/10.1016/j.red.2017.03.004

5. S.B. Holland, Journal of Corporate Finance, 46, 374-390 (2017), https://doi.org/10.1016/j.jcorpfin.2017.08.003

6. B. Jacobs, Labour Economics, 14, 913-925 (2007), https://doi.org/10.1016/j.labeco.2007.06.008

7. O. Pirogova, E. Gorin, V. Plotnikov, E3S Web of Conferences, 91, 08021 (2019)

8. V. Plotnikov, O. Pirogova, Key Competencies as an Enterprise Value Management Tool, IBIMA 2018, pp.1716-1721 (2018)

9. M. Martín-Peña, J. Sánchez-López, E. Díaz-Garrido, Journal of Business \& Industrial Marketing, 35(3), 564-574 (2019) https://doi.org/10.1108/JBIM-12-2018-0400

10. E. Fang, W.R. Palmatier, J.-B.E. Steenkamp, Journal of Marketing, 72, 1-14, (2008) https://doi.org/10.1509/jmkg.72.5.1

11. M.M. Hasan, Journal of Contemporary Accounting \& Economics, 13, 20-36 (2017) https://doi.org/10.1016/j.jcae.2017.01.002

12. K.M. Bakarich, M. Hossain, J. Weintrop, Journal of Contemporary Accounting and Economics, 15(1), 69-86, (2019) https://doi.org/10.1016/j.jcae.2018.12.002

13. O. Pirogova, V. Plotnikov, Z. Popovic, AISC 1116, 738-747, (2020) https://doi.org/10.1007/978-3-030-37919-3 73

14. A.A. Salisu, I.D. Raheem, U.B. Ndako, Resources Policy, 66, 101605, (2020) https://doi.org/10.1016/j.resourpol.2020.101605 
15. M. Sevilir, Journal of Financial Intermediation, 19, 483-508 (2010), https://doi.org/10.1016/j.jfi.2009.08.002

16. C. Christiansen, J. Joensen, H. Nielsen, Labour Economics, 14, 971-986 (2007), https://doi.org/10.1016/j.labeco.2007.06.001

17. B. Carmichael, A. Coën. Finance Research Letters, 32, 101172, (2020) https://doi.org/10.1016/j.frl.2019.04.029 